\title{
Uses of cardiomyocytes generated from induced pluripotent stem cells
}

Tung-Ying Lu and Lei Yang*

\begin{abstract}
Embryonic stem (ES) cells are naturally derived from early stage embryos and induced pluripotent stem (iPS) cells are reprogrammed from somatic cells with overexpression of four reprogramming factors, Oct4, Sox2, KIf4 and c-Myc. Both ES cells and iPS cells are pluripotent stem cells with capabilities of indefinite self-renewal and can be differentiated into almost all cell types of the body, which make them valuable for studying early developmental biology, for modeling and as therapy for human diseases. Specifically, human iPS cells could be utilized to generate patient-specific lineages for a variety of translational research. In this review, we describe the cardiac differentiation from ES cells, iPS cells, and the current progress of using iPS cell-derived cardiomyocytes for heart disease modeling and for the development of therapeutic strategies. In addition, we summarize the recent direct reprogramming of cardiomyocytes from fibroblast cells, which provides another method for potential heart disease therapy.
\end{abstract}

\section{Cardiomyocyte generation and purification from pluripotent embryonic stem cells}

Development of the cardiomyocyte lineage from in vitro cultured embryonic stem (ES) cells has been extensively studied in the past decades [1]. Mouse ES cells have been widely utilized as an in vitro model to study cardiogenesis, as cardiomyocytes were found to spontaneously differentiate from ES cells after withdrawal of LIF (leukemia inhibitory factor), which functions to maintain the pluripotency of undifferentiated mouse ES cells [2-4]. ES cells were aggregated into three-dimensional structures, termed embryoid bodies (EBs), and suspended in media containing fetal calf serum. Rhythmically contracting EBs

*Correspondence: lyang@pitt.edu

Department of Developmental Biology, University of Pittsburgh, 45th Street, 8117 Rangos Research Center, Pittsburgh, PA 15201, USA with electrophysiological characteristics were present after 8 to 10 days of induction [5,6], although the spontaneous differentiation efficiency was quite insufficient (Table 1). In order to improve the efficiency of cardiomyocyte differentiation from ES cells, chemical inducers such as dimethyl sulfoxide [7], all-trans retinoic acid [8], or 5-aza-2'-deoxycytidine [9], which were known to enhance cardiomyocyte differentiation in murine embryonic carcinoma (EC) P19 cells or mesenchymal stem cells, were introduced into mouse ES cell culture. In addition, several growth factors, including transforming growth factor- $\beta 2$ [10], Wnt11 [11], Nodal [12], basic fibroblast growth factor (bFGF), and bone morphogenetic protein (BMP)-2 [13], as well as other reagents such as nitric oxide [14], SPARC [15], S100A4 [16], and ascorbic acid [17], were used to promote cardiomyocyte differentiation from mouse ES cells. The differentiated ES cell cultures are heterogeneous and contain undifferentiated ES cells, which could result in teratoma formation after transplantation into the host. In order, therefore, to obtain a purified cardiomyocyte population from mouse ES cells, several approaches have been developed. Mouse ES cellderived EBs were dissociated using collagenase, followed with a modified procedure by Isenberg and Klockner in 1982 to prepare the calcium-tolerant ventricular myocytes [18]. Klug et al. in 1996 [19] reported another transgenic selection approach for purifying ES cell-derived cardiomyocytes. The neomycin-resistant gene driven by the cardiac $\alpha$-myosin heavy chain promoter was stably transfected into ES cells. After selection of neomycinresistant cells, the resulting cells were shown to be cardiomyocytes with high purity (>99\%) [19]. A similar approach was developed using a reporter green fluorescent protein (GFP) driven by the cardiac specific $\alpha$-actin promoter. And the GFP-positive cardiomyocytes were isolated by fluorescence-activated cell sorting (FACS) [20]. Mouse ES cell-derived cardiomyocytes formed stable engrafts in the mouse heart disease model and were extensively evaluated for their potential in tissue replacement therapy [1,19,21-24].

Seventeen years after the first establishment of mouse ES cell lines, the successful isolation and cultivation of ES cells of human origin was achieved [25,26]. Human ES 


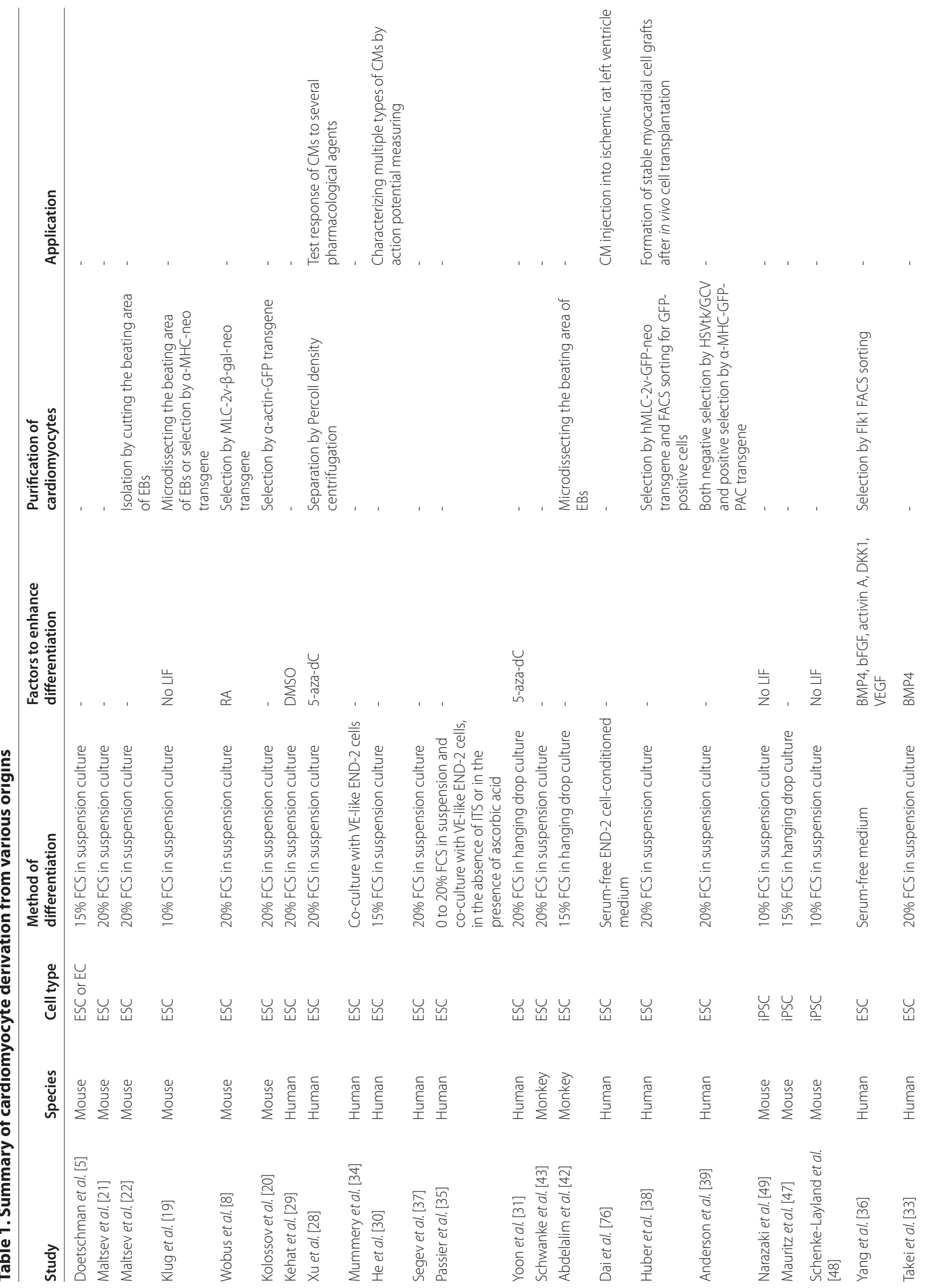




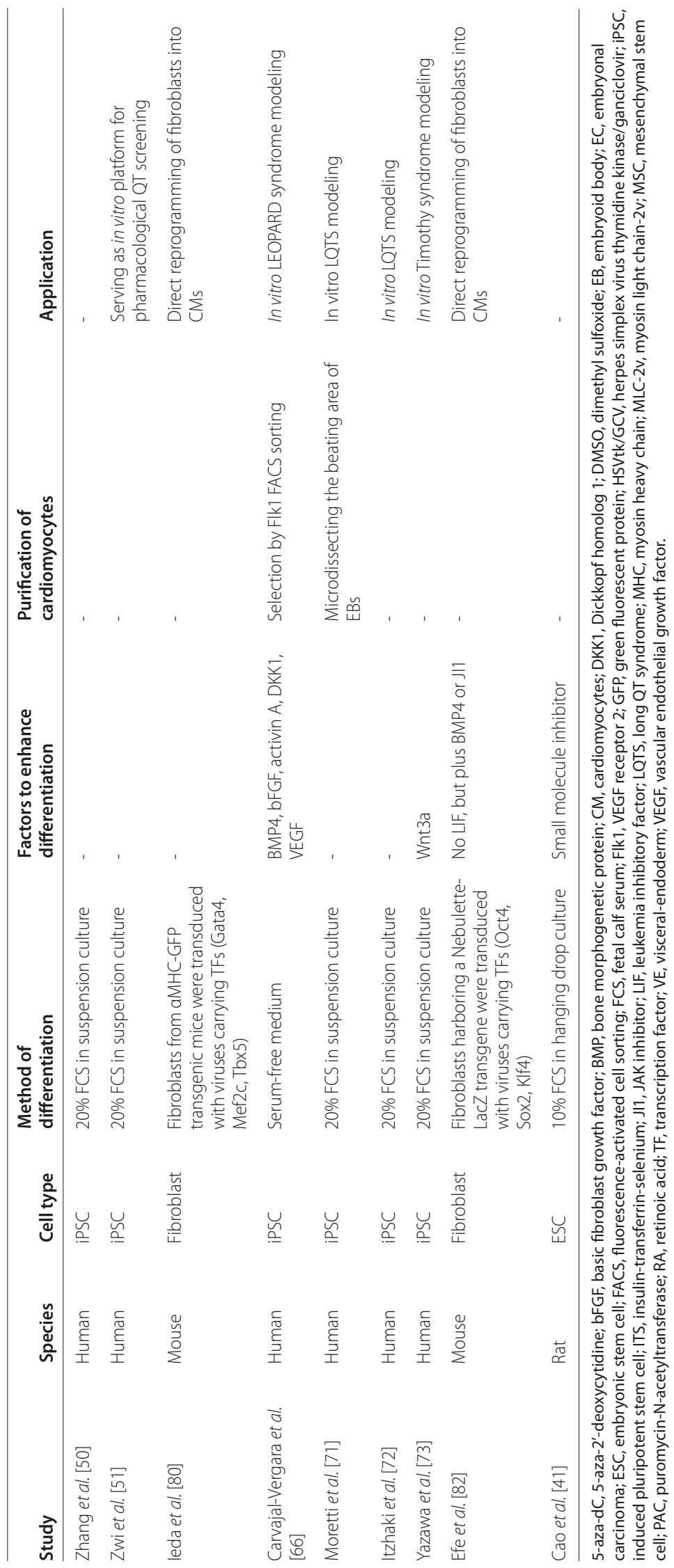


(hES) cells can be maintained in vitro for a prolonged period (approximately 250 population doublings), and have the capacity to differentiate into all three germ layer cells both in vitro and in vivo [25-27], which makes them an unlimited resource for providing various cell types for basic research, pharmacological testing, and potential therapeutic applications. Similar to mouse ES cells, spontaneously contracting cardiomyocytes of hES cells were detected when cultured in 15 to $20 \%$ fetal calf serum in the absence of the pluripotency-maintaining factor basic fibroblast growth factor [28-30]. Methods for cardiomyocyte induction from hES cells were mostly adapted from those used with mouse ES cells, such as addition of 5-aza-2'-deoxycytidine [28,31], and the growth factors BMP-2 [32] or BMP-4 [33] to enhance cardiomyocyte differentiation efficiency. In addition, a co-culture system has been developed to differentiate hES cells on top of mouse endoderm-like cells - the END-2 cell line - which were found to secrete some undefined cardiac inducers that promote hES cell differentiation [34,35]. However, most differentiation strategies remained suboptimal and could only induce approximately 5 to $25 \%$ cardiomyocytes from hES cells. Progress was made by Yang and colleagues in 2008 [36], when a staged protocol was established to induce cardiovascular differentiation from $\mathrm{hES}$ cells by following the biology of early heart development, which specifically yielded over $50 \%$ contracting cardiomyocytes after 20 days of differentiation (Figure 1a). In addition, Yang and colleagues isolated a multipotent cardiovascular progenitor population from hES cells and manipulated the specification of these progenitors into cardiomyocytes, smooth muscle cells and endothelial cells, which for the first time established an in vitro system to model early human heart formation using hES cells (Figure 1b).

As occurs with mouse ES cells, hES cell-derived cell cultures contain heterogeneous cell types. How to isolate cardiomyocytes from hES cell cultures with high efficiency and high purity remains a major challenge. Physical enrichment by manual dissection of beating areas or by Percoll gradient centrifugation has been utilized for cardiomyocyte enrichment [28,35,37]; however, the mixed undifferentiated hES cells within the cardiomyocytes prevented the future clinical use of the physically enriched cardiomyocytes. Therefore, genetically engineered hES lines that stably express drug-resistant genes within the cardiac cells were developed for cardiomyocyte enrichment. For example, a gene encoding an enhanced GFP-hyg resistant fusion protein driven by a human myosin light chain-2v promoter [38] or by the cardiacspecific human $\alpha$-myosin heavy chain promoter has been introduced into human H9 ES cells for cardiomyocyte selection [39]. High purity cardiomyocytes (99\%) were enriched from hES cells with the selection of GFPpositive cells or neomycin-resistant cells $[39,40]$. Although the drug selection method easily enriched more than $90 \%$ cardiomyocytes from hES cells, it has several limitations, such as virus integration, drug resistance, insufficient cardiomyocyte number and the difficulty of engineering each necessary ES cell line, which prevent the widespread use of this approach for generating a large quantity of healthy cardiomyocytes for future clinical use.

Recently, ES cell lines were established from other species such as rat [41] and monkey [42,43], and the derivation of cardiomyocytes from those ES cells described. Rat and monkey heart disease models could thus be used to evaluate functional improvements obtained following auto-transplantation of ES cell-derived cardiomyocytes, or the xenotransplantation of human ES/induced pluripotent stem (iPS) cell-derived cardiomyocytes. Rat- and monkey-derived cardiomyocytes could also be used to extensively study their functional characteristics, in vitro maturation, in vivo cell survival and functional integration.

\section{Cardiomyocyte differentiation from induced pluripotent stem cells}

Recently, the most exciting breakthrough in stem cell biology has been the established feasibility of reprogramming fibroblasts into iPS cells. Both mouse and human iPS cells have been generated by transduction of four reprogramming factors, Oct4, Sox2, Klf4 and c-Myc $[44,45]$, or another set of reprogramming factors, Oct4, Sox2, Nanog and Lin28 [46]. iPS cells are identical to ES cells morphologically and with regard to their gene expression profiles and the capability to form teratomas, and can differentiate in vitro into three germ layer cell types, including cardiomyocytes. Most of the protocols for cardiomyocyte induction from iPS cells were naturally adapted from ES cell studies. The cardiac differentiation of mouse iPS cells was carried out by Mauritz's group [47], who applied the EB-based differentiation protocol to mouse iPS cells and found that the final cell culture consisted of approximately 55\% beating EBs. Mouse iPS cells showed comparable cardiac differentiation potential to ES cells and had similar structural and electrophysiological characteristics to ES cell-derived cardiomyocytes. Similar results were reported by several other groups $[48,49]$. Although the robust differentiation capability of mouse iPS cells was demonstrated, cardiac differentiation from human iPS cells largely remains underdeveloped. In 2009, two groups demonstrated the derivation of functional cardiomyocytes from human iPS cells $[50,51]$. Human iPS cell-derived cardiomyocytes exhibit a fetallike phenotype and could be further designated as nodal-, atrial-, and ventricular-like cardiomyocyte subtypes [50]. However, the frequency of contracting EBs and 


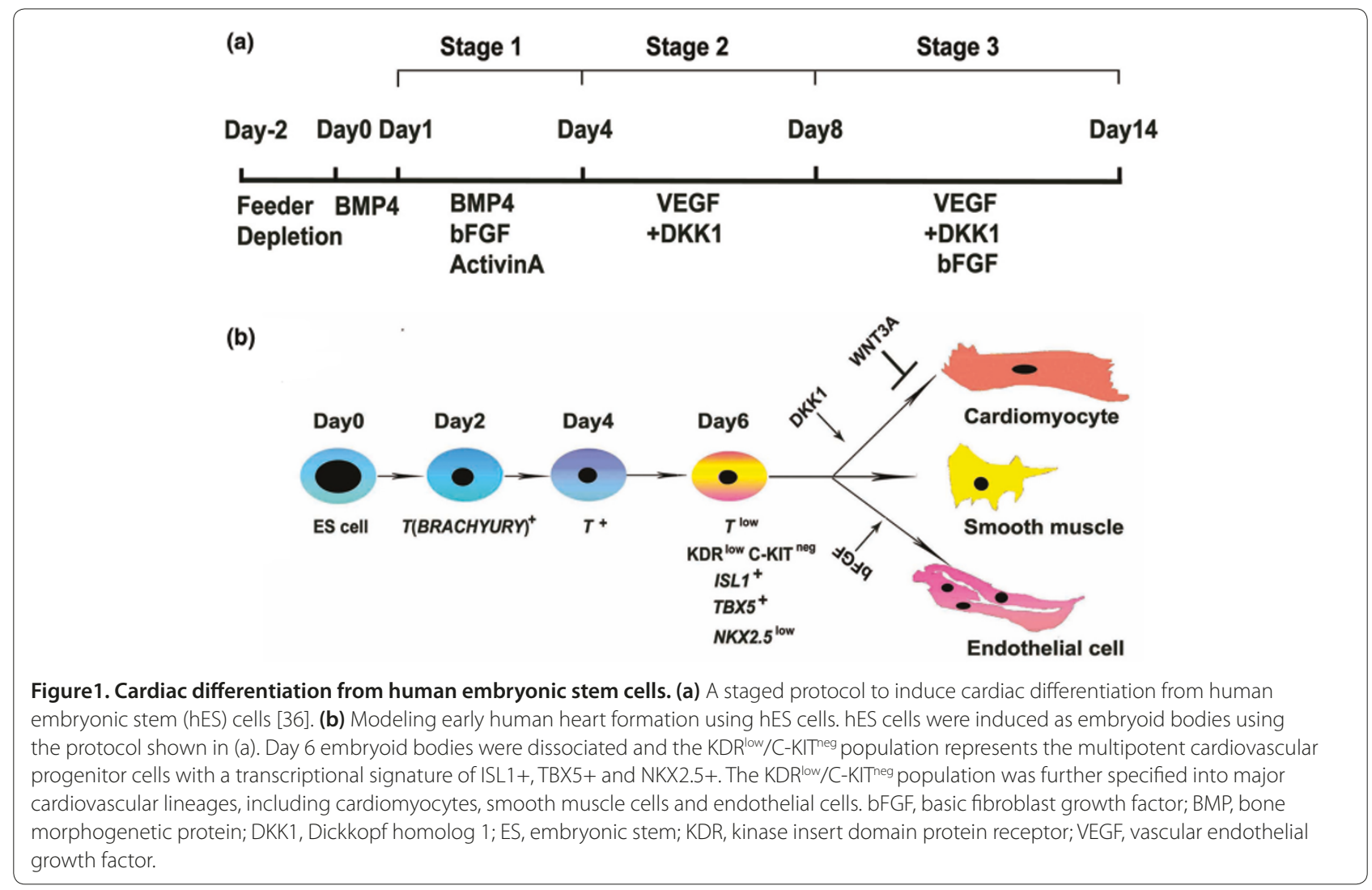

cardiomyocytes was very low (5 to $10 \%$ ) in those two studies. Therefore, a major challenge was to increase the efficiency of cardiomyocyte differentiation from human iPS cells. By using a similar protocol to that shown in Figure 1a, Kattman and colleagues [52] reported the highly efficient generation of cardiomyocytes from human iPS cells with the isolation of kinase insert domain receptor $(\mathrm{KDR})^{+}$platelet-derived growth factor receptor $(\text { PDGFR- } \alpha)^{+}$populations, which gave rise to over $60 \%$ cardiomyocytes after differentiation. Interestingly, we found that various iPS cell lines, or even different iPS cell clones originated from the same fibroblast line, exhibited different cardiac differentiation efficiencies (data not published). This difference may result from the different reprogramming strategies or different epigenetic backgrounds of each iPS cell line. The staged protocol shown in Figure 1a provides unique access to human iPS cellderived cardiovascular progenitor cells, as well as a substantial amount of cardiomyocytes, for a variety of studies.

Although cardiomyocytes could be generated from human iPS cells, the safety of iPS cell-derived cells must be rigorously tested before clinical trials on patients are conducted. In addition, iPS cells have been derived from other species such as rabbit [53], pig [54-57] and monkey $[58,59]$, although cardiomyocyte generation from these iPS cells has not been described.

\section{Use of induced pluripotent stem cell-derived cardiomyocytes}

Human iPS cells provide promising possibilities to bridge the gap between basic and clinical research and sustainable solutions for improving public health problems, such as human heart diseases. Heart disease is the leading cause of death in the United States, including coronary heart disease, ischemic heart disease, hypertensive heart disease, valvular heart disease and heart failure [60]. While both environmental and genetic factors contribute to heart disease, single-gene defects have been identified as the direct cause of more than 40 cardiovascular disorders, including hypertrophic cardiomyopathy and inherited arrhythmias such as familial long QT syndrome (LQTS), short QT syndrome and conduction system disorders [61]. Treatments for heart diseases include medication, device implantation, tissue ablation and eventually heart transplant. Heart disease therapy requires the development of patient-specific and diseasespecific drugs, new cell resources for replacement therapy, as well as, ultimately, the engineering of whole human heart organs for transplantation. The limited availability of human cardiomyocytes is, however, a major obstacle for such progress. To date, animal models and non-human cardiomyocytes are still widely used as a major resource in these studies [62-65]. Human iPS 


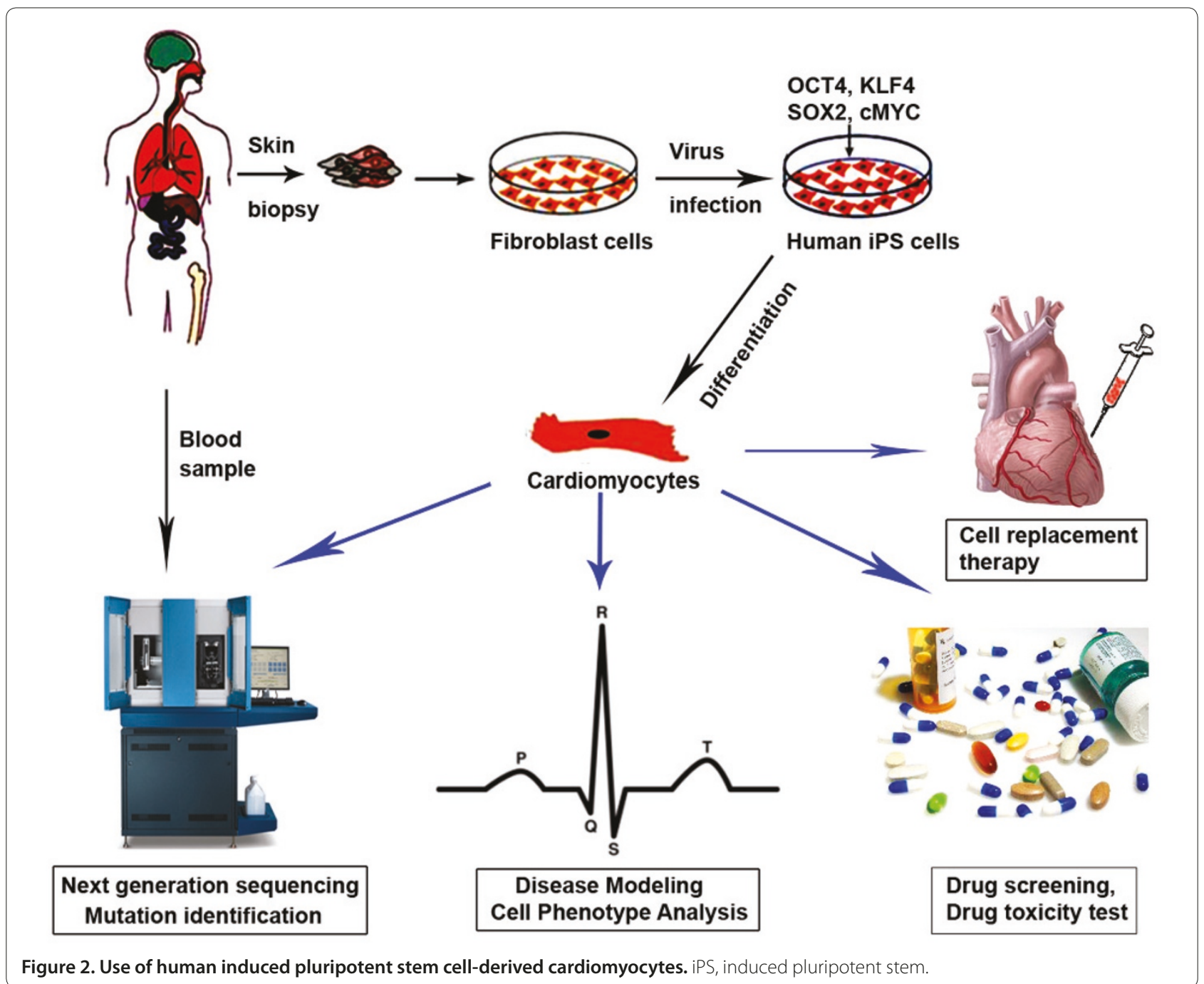

cell-derived cardiomyocytes are renewable and free of the secondary abnormalities that result from end-stage disease, comorbidities, and prolonged pharmaceutical therapy. Thus, they offer an unprecedented opportunity to generate patient-specific lineages for disease modeling, drug screening, drug safety testing and potential cell replacement therapy of heart disease (Figure 2).

Given the complexities of many heart diseases, the first heart disease modeling studies focused on heart diseases caused by single gene mutations, which result in the disease phenotypes shown by single iPS cell-derived cardiomyocytes. To date, cardiac hypertrophy and cardiac channelopathy have been modeled using patient iPS cell-derived cardiomyocytes.

Carvajal-Vergara and colleagues [66] generated iPS cell lines from patients with LEOPARD syndrome (LS) and non-affected controls. Approximately $40 \%$ of LS patients exhibit cardiac hypertrophy. LS iPS cells have a single T468M mutation in the gene PTPN11 (protein tyrosine phosphatase, non-receptor type 11), the same genetic defect as in their parents. Interestingly, the authors detected the hypertrophic phenotype in cardiomyocytes derived from iPS cells from LS patients, which was confirmed by the enlarged cell size, abnormal sarcomeric organization and nuclear localization of NFATC.

Modeling of cardiac channelopathy has been reported by several groups. A subtype of cardiac arrhythmias, LQTS has been modeled using patient-derived iPS cells. Mutations of 12 genes (KCNQ1, KCNH2, SCN5A, ANK2, KCNE1, KCNE2, KCNJ2, CACNA1C, CAV3, SCN4B, $A K A P 9$, and SNTA1) have been identified as the major cause of inheritable LQTS. Most of the disease-causing genes encode ion channels [67]. LQTS leads to palpitations and a high risk of sudden death due to ventricular fibrillation, especially in the young [68-70]. These mutations prolong the duration of the ventricular action potential, thus increasing the QT interval. The most common causes of LQTS are mutations in the 
voltage-gated $\mathrm{K}^{+}$channel genes, including KCNQ1 (type 1 LQTS (LQT1)) and KCNH2 (type 2 LQTS (LQT2)), and in the voltage-gated $\mathrm{Na}^{+}$channel gene $S C N 5 A$ (type 3 LQTS (LQT3)), which together account for more than $60 \%$ of inherited LQTS cases [67]. The abnormalities of LQTS can be readily detected at the single cell level with electrophysiological assays such as the patch clamp, which makes LQTS an ideal heart disease to model with iPS cell-derived cardiomyocytes. Several groups have thus investigated the feasibility of modeling LQT1 [71], LQT2 [72], and Timothy syndrome (LQT3) [73] using patient-derived iPS cells. Cardiomyocytes derived from iPS cells of those patients recapitulated a delayed rectifier ion current, a typical phenotype detected in patients. Some studies have also tested the response of cardiomyocytes derived from iPS cells of LQT patients to pharmaceutical agents [72,73]. All these studies represent a promising paradigm to understand the mechanism of human inherited heart disease and to develop novel drugs for disease therapy.

These ground-breaking discoveries opened a new era in the study of heart disease using patient-derived iPS cells. However, the molecular etiology of these inherited heart diseases has not been clearly addressed. The reason lies in the difficulty of enriching a large number of purified cardiomyocytes from iPS cell cultures. In addition, single cardiomyocytes derived from iPS cells from LS and LQTS patients recapitulated only some aspects of the disease phenotype in two-dimensional cultures. For example, the susceptibility of single cardiomyocytes derived from iPS cells of LQTS patients to drug stimulation was different to that of the human heart [72]. Given the fact that the heart is a complex structured organ with coupled ion influxes and electrical conductivity, it would be of great importance to investigate the mechanisms of heart diseases, especially abnormal electrical conductivities in cardiac arrhythmias, using a three-dimensional heart tissue engineered from cardiomyocytes derived from diseased iPS cells.

Another advantage of human iPS/ES cell-derived cardiomyocytes is that they can be used as an in vitro model for drug safety testing because they originated from human and are scalable and reproducible in vitro. The first attempt at in vitro drug testing was reported by Braam and colleagues [74]; hES cell-derived cardiomyocytes revealed dose-dependent responses to 12 cardiac and noncardiac drugs, which could lead to the development of new drugs for the therapy of heart diseases. Thus, human iPS cell-derived cardiomyocytes can provide a novel patient-specific or disease-specific system for drug safety testing and drug screening.

The potential use of hES cell-derived cardiomyocytes for cell replacement therapy was reported several years ago [75-77]. hES cell-derived cardiomyocytes were introduced into rodent heart disease models, resulting in functional improvements. However, research in this field remains underdeveloped, mainly because of poor engraftment efficiency after intra-myocardial transplantation into the myocardial infarction models [76,78]. Studies have suggested that the low engraftment efficiency may be partly due to suboptimal cell resources, poor cell delivery, apoptosis of donor cells, and immunological rejection [76,79]. In addition, because of the differences in the physiological and dynamic environments of rodent and human hearts, long-term integration of engraftment with hES cell-derived cardiomyocytes has not been detected. A better strategy is to utilize large animal models to study this as the electrophysiological characteristics of rodents are different from those of human. One ultimate goal of regenerative medicine is to transplant human iPS cell-derived cardiomyocytes in order to repair the damaged heart. However, safety concerns regarding virus integration during iPS cell reprogramming, the efficiency of cardiomyocyte generation from human iPS cell lines, the potential for tumor formation from mixed pluripotent iPS cells within the engrafts, and the fetal-like phenotype of iPS cell-derived cardiomyocytes are major obstacles in this field.

\section{Direct reprogramming of somatic cells into cardiomyocytes}

Ieda and colleagues reported the direct reprogramming of mouse fibroblasts into induced cardiomyocytes (iCMs) through the introduction of three factors: Gata4, Mef2c and Tbx5 [80]. By comparing microarray data from cardiomyocytes and cardiac fibroblasts [81], the authors selected 14 candidate factors that play key roles in cardiac differentiation. Of these 14 candidates, Gata4, Mef2c and Tbx 5 were identified as the master reprogramming factors, responsible for the generation of 5\% cTNT (a thin filament protein specifically shown in a contractile complex in cardiomyocyte) positive cardiomyocytes from cardiac fibroblasts. Interestingly, the iCMs showed similarity to mature mouse ventricular cardiomyocytes. This study shed new light on studies of heart development and possible clinical applications, yet this system has not been extended to human cells and this finding has not been confirmed by other groups.

Alternatively, mouse fibroblasts were reprogrammed into cardiomyocytes by four iPS cell reprogramming factors (Oct4, Sox2, Klf4 and c-Myc) combined with a chemically defined differentiation medium [82]. Spontaneously contracting cells were present in the culture from day 11 . At day 18 , over $50 \%$ of the cells had started beating, and this could reach $80 \%$ of cells after extended culture. The functional characteristics of these cells were assayed by calcium flux recording and electrophysiological tests. Overall, the authors claimed a 
direct reprogramming of fibroblasts into cardiomyocytes without the pluripotent state. However, considering the use of iPS cell reprogramming factors and the very fast differentiation of mouse ES/iPS cells into cardiomyocytes (normally within 5 to 6 days), it is likely this method initially converted fibroblast cells into an early pluripotent state followed by immediate cardiomyocyte commitment. Given the much longer time windows for human iPS cell reprogramming and for cardiomyocyte differentiation from human ES/iPS cells, confirmation of this direct reprogramming strategy with human cells would provide more details on the underlying mechanisms.

To date, iPS cells have been generated from various somatic cell types, including fibroblasts [44], blood [83,84], melanocytes [85], pancreatic $\beta$ cells [86], and neural progenitors $[87,88]$. Interestingly, early passage iPS cells were found to retain a transient epigenetic memory of their original tissue type, which influenced their subsequent differentiation capability $[89,90]$. Studies from Srivastava's group [80] showed that iCMs exhibit a mature ventricular cardiomyocyte phenotype and heartderived fibroblasts gave rise to two-fold more iCMs than tail-derived dermal fibroblasts, indicating that the epigenetic memory of fibroblasts could affect the derivation of iCMs. All these studies strongly suggested that the tissue origin or tissue memory of fibroblasts could affect the reprogramming of iPS cells, as well as the further differentiation of iPS cells into various lineages.

\section{Conclusion}

Spontaneously beating cardiomyocytes have been detected from ES cells cultured in the absence of factors supporting self-renewal. For the past decade, however, the efficiency of generation and purity of ES cell-derived cardiomyocytes remain largely unsatisfactory. Recent progress established a staged protocol to efficiently induce cardiac differentiation from ES cells by recapitulating the early events of heart formation (Figure 1a), which for the first time provided a large amount of multipotent cardiovascular progenitor cells. Thus, ES cells can be used to model early human heart formation and be utilized as a tool to address early heart determination and specification in vitro. However, ethical issues with hES cells have prevented the widespread use of ES cells and their differentiated progenies. With the breakthrough of iPS cells, pluripotent stem cells can be easily converted from somatic cells without requiring embryos. Most importantly, iPS cell technology opens a new era in obtaining unlimited patient-specific lineage cells, which will harbor the same genetic defects as the patients. Cardiomyocytes derived from patient-specific iPS cells would greatly accelerate the understanding of human inherited heart diseases and benefit drug development and potential cell replacement therapies for human heart disease. Although issues such as virus safety, tumor formation after transplantation and nonpurified donor cells are current hurdles to the direct use of iPS cell-derived cardiomyocytes for clinical use, iPS cells so far provide the most promising resource for scientists to eventually bridge the gap between basic research and sustainable solutions for the treatment of human heart disease.

This article is part of a review series on Induced pluripotent stem cells. Other articles in the series can be found online at

http://stemcellres.com/series/ipsc

\section{Abbreviations}

BMP, bone morphogenetic protein; EB, embryoid body; ES, embryonic stem GFP, green fluorescent protein; hES, human embryonic stem; iCM, induced cardiomyocyte; iPS, induced pluripotent stem; KDR, kinase insert domain protein receptor; LQTS, long QT syndrome; LS, LEOPARD syndrome.

\section{Competing interests}

The authors declare that they have no competing interests.

\section{Authors' contributions}

LY prepared the figures. Both authors contributed to the writing of the manuscript, and read and approved the final version.

\section{Acknowledgements}

This work was supported by AHA SDG grant \#1 1SDG5580002 (to LY) and by National Science Council (Taiwan) grant \# NSC100-2917-I-564-015 (to T-YL).

Published:18 November 2011

\section{References}

1. Hescheler J, Fleischmann BK, Lentini S, Maltsev VA, Rohwedel J, Wobus AM, Addicks K: Embryonic stem cells: a model to study structural and functional properties in cardiomyogenesis. Cardiovasc Res 1997, 36:149-162.

2. Evans MJ, Kaufman MH: Establishment in culture of pluripotential cells from mouse embryos. Nature 1981, 292:154-156.

3. Martin GR: Isolation of a pluripotent cell line from early mouse embryos cultured in medium conditioned by teratocarcinoma stem cells. Proc Natl Acad Sci U S A 1981, 78:7634-7638.

4. Wobus AM, Holzhausen $\mathrm{H}$, Jakel P, Schoneich J: Characterization of a pluripotent stem cell line derived from a mouse embryo. Exp Cell Res 1984, 152:212-219

5. Doetschman TC, Eistetter H, Katz M, Schmidt W, Kemler R: The in vitro development of blastocyst-derived embryonic stem cell lines: formation of visceral yolk sac, blood islands and myocardium. J Embryol Exp Morphol 1985, 87:27-45.

6. Wobus AM, Wallukat G, Hescheler J: Pluripotent mouse embryonic stem cells are able to differentiate into cardiomyocytes expressing chronotropic responses to adrenergic and cholinergic agents and $\mathrm{Ca} 2+$ channel blockers. Differentiation 1991, 48:173-182.

7. Edwards MK, Harris JF, McBurney MW: Induced muscle differentiation in an embryonal carcinoma cell line. Mol Cell Biol 1983, 3:2280-2286.

8. Wobus AM, Kaomei G, Shan J, Wellner MC, Rohwedel J, Ji G, Fleischmann B, Katus HA, Hescheler J, Franz WM: Retinoic acid accelerates embryonic stem cell-derived cardiac differentiation and enhances development of ventricular cardiomyocytes. J Mol Cell Cardiol 1997, 29:1525-1539.

9. Fukuda K: Development of regenerative cardiomyocytes from mesenchymal stem cells for cardiovascular tissue engineering. Artif Organs 2001, 25:187-193.

10. Singla $D K$, Sun $B$ : Transforming growth factor-beta2 enhances differentiation of cardiac myocytes from embryonic stem cells. Biochem Biophys Res Commun 2005, 332:135-141. 
11. Terami H, Hidaka K, Katsumata T, lio A, Morisaki T: Wnt11 facilitates embryonic stem cell differentiation to Nkx2.5-positive cardiomyocytes. Biochem Biophys Res Commun 2004, 325:968-975

12. Parisi S, D'Andrea D, Lago CT, Adamson ED, Persico MG, Minchiotti G: Nodaldependent Cripto signaling promotes cardiomyogenesis and redirects the neural fate of embryonic stem cells. J Cell Bio/ 2003, 163:303-314.

13. Kawai T, Takahashi T, Esaki M, Ushikoshi H, Nagano S, Fujiwara H, Kosai K Efficient cardiomyogenic differentiation of embryonic stem cell by fibroblast growth factor 2 and bone morphogenetic protein 2. Circ J 2004 68:691-702.

14. Kanno S, Kim PK, Sallam K, Lei J, Billiar TR, Shears LL 2nd: Nitric oxide facilitates cardiomyogenesis in mouse embryonic stem cells. Proc Natl Acad Sci U S A 2004, 101:12277-12281.

15. Stary M, Pasteiner W, Summer A, Hrdina A, Eger A, Weitzer G: Parietal endoderm secreted SPARC promotes early cardiomyogenesis in vitro. Exp Cell Res 2005, 310:331-343.

16. Stary M, Schneider M, Sheikh SP, Weitzer G: Parietal endoderm secreted S100A4 promotes early cardiomyogenesis in embryoid bodies. Biochem Biophys Res Commun 2006, 343:555-563.

17. Takahashi T, Lord B, Schulze PC, Fryer RM, Sarang SS, Gullans SR, Lee RT: Ascorbic acid enhances differentiation of embryonic stem cells into cardiac myocytes. Circulation 2003, 107:1912-1916.

18. Isenberg G, Klockner U: Calcium tolerant ventricular myocytes prepared by preincubation in a "KB medium". Pflugers Arch 1982, 395:6-18.

19. Klug MG, Soonpaa MH, Koh GY, Field L: Genetically selected cardiomyocytes from differentiating embronic stem cells form stable intracardiac grafts. J Clin Invest 1996, 98:216-224.

20. Kolossov E, Fleischmann BK, Liu Q, Bloch W, Viatchenko-Karpinski S, Manzke $\mathrm{O}$, Ji GJ, Bohlen H, Addicks K, Hescheler J: Functional characteristics of ES cell-derived cardiac precursor cells identified by tissue-specific expression of the green fluorescent protein. J Cell Bio/ 1998, 143:2045-2056.

21. Maltsev VA, Rohwedel J, Hescheler J, Wobus AM: Embryonic stem cells differentiate in vitro into cardiomyocytes representing sinusnodal, atrial and ventricular cell types. Mech Dev 1993, 44:41-50.

22. Maltsev VA, Wobus AM, Rohwedel J, Bader M, Hescheler J: Cardiomyocytes differentiated in vitro from embryonic stem cells developmentally express cardiac-specific genes and ionic currents. Circ Res 1994, 75:233-244.

23. Maltsev VA, Ji GJ, Wobus AM, Fleischmann BK, Hescheler J: Establishment of beta-adrenergic modulation of L-type Ca2+ current in the early stages of cardiomyocyte development. Circ Res 1999, 84:136-145.

24. Wobus AM, Rohwedel J, Maltsev V, Hescheler J: Development of cardiomyocytes expressing cardiac-specific genes, action potentials, and ionic channels during embryonic stem cell-derived cardiogenesis. Ann NY Acad Sci 1995, 752:460-469.

25. Thomson JA, Itskovitz-Eldor J, Shapiro SS, Waknitz MA, Swiergiel JJ, Marshall VS, Jones JM: Embryonic stem cell lines derived from human blastocysts. Science 1998, 282:1145-1147.

26. Reubinoff BE, Pera MF, Fong CY, Trounson A, Bongso A: Embryonic stem cel lines from human blastocysts: somatic differentiation in vitro. Nat Biotechnol 2000, 18:399-404.

27. Amit M, Carpenter MK, Inokuma MS, Chiu CP, Harris CP, Waknitz MA, ItskovitzEldor J, Thomson JA: Clonally derived human embryonic stem cell lines maintain pluripotency and proliferative potential for prolonged periods of culture. Dev Bio/ 2000, 227:271-278

28. Xu C, Police S, Rao N, Carpenter MK: Characterization and enrichment of cardiomyocytes derived from human embryonic stem cells. Circ Res 2002, 91:501-508.

29. Kehat I, Kenyagin-Karsenti D, Snir M, Segev H, Amit M, Gepstein A, Livne E, Binah O, Itskovitz-Eldor J, Gepstein L: Human embryonic stem cells can differentiate into myocytes with structural and functional properties of cardiomyocytes. J Clin Invest 2001, 108:407-414.

30. He JQ, Ma Y, Lee Y, Thomson JA, Kamp TJ: Human embryonic stem cells develop into multiple types of cardiac myocytes: action potential characterization. Circ Res 2003, 93:32-39.

31. Yoon BS, Yoo SJ, Lee JE, You S, Lee HT, Yoon HS: Enhanced differentiation of human embryonic stem cells into cardiomyocytes by combining hanging drop culture and 5-azacytidine treatment. Differentiation 2006, 74:149-159.

32. Pal $R$, Khanna A: Similar pattern in cardiac differentiation of human embryonic stem cell lines, BG01V and ReliCellhES1, under low serum concentration supplemented with bone morphogenetic protein- 2 . Differentiation 2007, 75:112-122.
33. Takei S, Ichikawa H, Johkura K, Mogi A, No H, Yoshie S, Tomotsune D, Sasaki K: Bone morphogenetic protein-4 promotes induction of cardiomyocytes from human embryonic stem cells in serum-based embryoid body development. Am J Physiol Heart Circ Physiol 2009, 296:H1793-1803.

34. Mummery C, Ward-van Oostwaard D, Doevendans P, Spijker R, van den Brink S, Hassink R, van der Heyden M, Opthof T, Pera M, de la Riviere AB, Passier R, Tertoolen L: Differentiation of human embryonic stem cells to cardiomyocytes: role of coculture with visceral endoderm-like cells. Circulation 2003, 107:2733-2740.

35. Passier R, Oostwaard DW, Snapper J, Kloots J, Hassink RJ, Kuijk E, Roelen B, de la Riviere AB, Mummery C: Increased cardiomyocyte differentiation from human embryonic stem cells in serum-free cultures. Stem Cells 2005, 23:772-780.

36. Yang L, Soonpaa MH, Adler ED, Roepke TK, Kattman SJ, Kennedy M, Henckaerts E, Bonham K, Abbott GW, Linden RM, Field L, Keller GM: Human cardiovascular progenitor cells develop from a KDR+ embryonic-stemcell-derived population. Nature 2008, 453:524-528.

37. Segev H, Kenyagin-Karsenti D, Fishman B, Gerecht-Nir S, Ziskind A, Amit M, Coleman R, Itskovitz-Eldor J: Molecular analysis of cardiomyocytes derived from human embryonic stem cells. Dev Growth Differ 2005, 47:295-306.

38. Huber I, Itzhaki I, Caspi O, Arbel G, Tzukerman M, Gepstein A, Habib M, Yankelson L, Kehat I, Gepstein L: Identification and selection of cardiomyocytes during human embryonic stem cell differentiation. FASEB J 2007, 21:2551-2563.

39. Anderson D, SelfT, Mellor IR, Goh G, Hill SJ, Denning C: Transgenic enrichment of cardiomyocytes from human embryonic stem cells. $\mathrm{Mol}$ Ther 2007, 15:2027-2036.

40. Xu XQ, Zweigerdt R, Soo SY, Ngoh ZX, Tham SC, Wang ST, Graichen R, Davidson B, Colman A, Sun W: Highly enriched cardiomyocytes from human embryonic stem cells. Cytotherapy 2008, 10:376-389.

41. Cao N, Liao J, Liu Z, Zhu W, Wang J, Liu L, Yu L, Xu P, Cui C, Xiao L, Yang HT: In vitro differentiation of rat embryonic stem cells into functional cardiomyocytes. Cell Res 2011, 21:1316-1331.

42. Abdelalim EM, Takada T, Toyoda F, Omatsu-Kanbe M, Matsuura H, Tooyama I, Torii R: In vitro expression of natriuretic peptides in cardiomyocytes differentiated from monkey embryonic stem cells. Biochem Biophys Res Commun 2006, 340:689-695.

43. Schwanke K, Wunderlich S, Reppel M, Winkler ME, Matzkies M, Groos S, Itskovitz-Eldor J, Simon AR, Hescheler J, Haverich A, Martin U: Generation and characterization of functional cardiomyocytes from rhesus monkey embryonic stem cells. Stem Cells 2006, 24:1423-1432.

44. Takahashi K, Yamanaka S: Induction of pluripotent stem cells from mouse embryonic and adult fibroblast cultures by defined factors. Cell 2006, 126:663-676.

45. Takahashi K, Tanabe K, Ohnuki M, Narita M, Ichisaka T, Tomoda K, Yamanaka S Induction of pluripotent stem cells from adult human fibroblasts by defined factors. Cell 2007, 131:861-872

46. Yu J, Vodyanik MA, Smuga-Otto K, Antosiewicz-Bourget J, Frane JL, Tian S, Nie J, Jonsdottir GA, Ruotti V, Stewart R, Slukvin II, Thomson JA: Induced pluripotent stem cell lines derived from human somatic cells. Science 2007 318:1917-1920.

47. Mauritz C, Schwanke K, Reppel M, Neef S, Katsirntaki K, Maier LS, Nguemo F, Menke S, Haustein M, Hescheler J, Hasenfuss G, Martin U: Generation of functional murine cardiac myocytes from induced pluripotent stem cells. Circulation 2008, 118:507-517.

48. Schenke-Layland K, Rhodes KE, Angelis E, Butylkova Y, Heydarkhan-Hagvall S, Gekas C, Zhang R, Goldhaber Jl, Mikkola HK, Plath K, MacLellan WR: Reprogrammed mouse fibroblasts differentiate into cells of the cardiovascular and hematopoietic lineages. Stem Cells 2008, 26:1537-1546.

49. Narazaki G, Uosaki H, Teranishi M, Okita K, Kim B, Matsuoka S, Yamanaka S, Yamashita JK: Directed and systematic differentiation of cardiovascular cells from mouse induced pluripotent stem cells. Circulation 2008 118:498-506

50. Zhang J, Wilson GF, Soerens AG, Koonce CH, Yu J, Palecek SP, Thomson JA, Kamp TJ: Functional cardiomyocytes derived from human induced pluripotent stem cells. Circ Res 2009, 104:e30-41.

51. Zwi L, Caspi O, Arbel G, Huber I, Gepstein A, Park IH, Gepstein L: Cardiomyocyte differentiation of human induced pluripotent stem cells. Circulation 2009, 120:1513-1523.

52. Kattman SJ, Witty AD, Gagliardi M, Dubois NC, Niapour M, Hotta A, Ellis J, Keller G: Stage-specific optimization of activin/nodal and BMP signaling 
promotes cardiac differentiation of mouse and human pluripotent stem cell lines. Cell Stem Cell 2011, 8:228-240.

53. Honda A, Hirose M, Hatori M, Matoba S, Miyoshi H, Inoue K, Ogura A: Generation of induced pluripotent stem cells in rabbits: potential experimental models for human regenerative medicine. J Biol Chem, 285:31362-31369.

54. Ezashi T, Telugu BP, Alexenko AP, Sachdev S, Sinha S, Roberts RM: Derivation of induced pluripotent stem cells from pig somatic cells. Proc Natl Acad SC USA 2009, 106:10993-10998.

55. Wu Z, Chen J, Ren J, Bao L, Liao J, Cui C, Rao L, Li H, Gu Y, Dai H, Zhu H, Teng X, Cheng $L$, Xiao $L$ : Generation of pig induced pluripotent stem cells with a drug-inducible system. J Mol Cell Biol 2009, 1:46-54.

56. Esteban MA, Xu J, Yang J, Peng M, Qin D, Li W, Jiang Z, Chen J, Deng K, Zhong M, Cai J, Lai L, Pei D: Generation of induced pluripotent stem cell lines from Tibetan miniature pig. J Biol Chem 2009, 284:17634-17640.

57. West FD, Terlouw SL, Kwon DJ, Mumaw JL, Dhara SK, Hasneen K, Dobrinsky $J R$, Stice SL: Porcine induced pluripotent stem cells produce chimeric offspring. Stem Cells Dev 2010, 19:1211-1220.

58. Wu Y, Zhang Y, Mishra A, Tardif SD, Hornsby PJ: Generation of induced pluripotent stem cells from newborn marmoset skin fibroblasts. Stem Cell Res 2010, 4:180-188

59. Liu H, Zhu F, Yong J, Zhang P, Hou P, Li H, Jiang W, Cai J, Liu M, Cui K, Qu X, Xiang T, Lu D, Chi X, Gao G, Ji W, Ding M, Deng H: Generation of induced pluripotent stem cells from adult rhesus monkey fibroblasts. Cell Stem Cell 2008, 3:587-590

60. Jemal A, Ward E, Hao Y, Thun M: Trends in the leading causes of death in the United States, 1970-2002. JAMA 2005, 294:1255-1259.

61. Kelly M, Semsarian C: Multiple mutations in genetic cardiovascular disease: a marker of disease severity? Circ Cardiovasc Genet 2009, 2:182-190.

62. Harris SP, Bartley CR, Hacker TA, McDonald KS, Douglas PS, Greaser ML, Powers PA, Moss RL: Hypertrophic cardiomyopathy in cardiac myosin binding protein-C knockout mice. Circ Res 2002, 90:594-601.

63. Amin AS, Herfst $L J$, Delisle BP, Klemens $C A$, Rook MB, Bezzina CR, Underkofler HA, Holzem KM, Ruijter JM, Tan HL, January CT, Wilde AA: Fever-induced QTC prolongation and ventricular arrhythmias in individuals with type 2 congenital long QT syndrome. J Clin Invest 2008, 118:2552-2561.

64. Aizawa Y, Ueda K, Scornik F, Cordeiro JM, Wu Y, Desai M, Guerchicoff A, Nagata Y, lesaka Y, Kimura A, Hiraoka M, Antzelevitch C: A novel mutation in KCNQ1 associated with a potent dominant negative effect as the basis for the LQT1 form of the long QT syndrome. J Cardiovasc Electrophysio/ 2007, 18:972-977.

65. Wu Y, Temple J, Zhang R, Dzhura I, Zhang W, Trimble R, Roden DM, Passier R, Olson EN, Colbran RJ, Anderson ME: Calmodulin kinase II and arrhythmias in a mouse model of cardiac hypertrophy. Circulation 2002, 106:1288-1293.

66. Carvajal-Vergara X, Sevilla A, D'Souza SL, Ang YS, Schaniel C, Lee DF, Yang L, Kaplan AD, Adler ED, Rozov R, Ge Y, Cohen N, Edelmann LJ, Chang B, Waghray A, Su J, Pardo S, Lichtenbelt KD, Tartaglia M, Gelb BD, Lemischka IR: Patientspecific induced pluripotent stem-cell-derived models of LEOPARD syndrome. Nature 2010, 465:808-812.

67. Hedley PL, Jorgensen P, Schlamowitz S, Wangari R, Moolman-Smook J, Brink PA, Kanters JK, Corfield VA, Christiansen M: The genetic basis of long QT and short QT syndromes: a mutation update. Hum Mutat 2009, 30:1486-1511.

68. Priori SG: Arrhythmias: Unexplained sudden cardiac death--back to clinical evaluation. Nat Rev Cardiol 2009, 6:678-679.

69. Krahn AD, Healey JS, Chauhan V, Birnie DH, Simpson CS, Champagne J, Gardner M, Sanatani S, Exner DV, Klein GJ, Yee R, Skanes AC, Gula LJ, Gollob $\mathrm{MH}$ : Systematic assessment of patients with unexplained cardiac arrest: Cardiac Arrest Survivors With Preserved Ejection Fraction Registry (CASPER). Circulation 2009, 120:278-285.

70. Alexander ME, Berul Cl: Ventricular arrhythmias: when to worry. Pediatr Cardiol 2000, 21:532-541.

71. Moretti A, Bellin M, Welling A, Jung CB, Lam JT, Bott-Flügel L, Dorn T, Goedel A, Höhnke C, Hofmann F, Seyfarth M, Sinnecker D, Schömig A, Laugwitz KL: Patient-specific induced pluripotent stem-cell models for long-QT syndrome. N Eng/ J Med 2010, 363:1397-1409.

72. Itzhaki I, Maizels L, Huber I, Zwi-Dantsis L, Caspi O, Winterstern A, Feldman O, Gepstein A, Arbel G, Hammerman H, Boulos M, Gepstein L: Modelling the long QT syndrome with induced pluripotent stem cells. Nature 2011, 471:225-229.

73. Yazawa M, Hsueh B, Jia X, Pasca AM, Bernstein JA, Hallmayer J, Dolmetsch RE:
Using induced pluripotent stem cells to investigate cardiac phenotypes in Timothy syndrome. Nature 2011, 471:230-234.

74. Braam SR, Tertoolen L, van de Stolpe A, Meyer T, Passier R, Mummery CL: Prediction of drug-induced cardiotoxicity using human embryonic stem cell-derived cardiomyocytes. Stem Cell Res 2009, 4:107-116.

75. Gepstein L, Ding C, Rehemedula D, Wilson EE, Yankelson L, Caspi O, Gepstein A, Huber I, Olgin JE: In vivo assessment of the electrophysiological integration and arrhythmogenic risk of myocardial cell transplantation strategies. Stem Cells 2010, 28:2151-2161.

76. Dai W, Field LJ, Rubart M, Reuter S, Hale SL, Zweigerdt R, Graichen RE, Kay GL, Jyrala AJ, Colman A, Davidson BP, Pera M, Kloner RA: Survival and maturation of human embryonic stem cell-derived cardiomyocytes in rat hearts. $J \mathrm{Mol}$ Cell Cardio/ 2007, 43:504-516.

77. van Laake LW, Passier R, Monshouwer-Kloots J, Verkleij AJ, Lips DJ, Freund C, den Ouden K, Ward-van Oostwaard D, Korving J, Tertoolen LG, van Echteld CJ, Doevendans PA, Mummery CL: Human embryonic stem cell-derived cardiomyocytes survive and mature in the mouse heart and transiently improve function after myocardial infarction. Stem Cell Res 2007, 1:9-24.

78. van Laake LW, Passier R, den Ouden K, Schreurs C, Monshouwer-Kloots J, Ward-van Oostwaard D, van Echteld CJ, Doevendans PA, Mummery CL: Improvement of mouse cardiac function by hESC-derived cardiomyocytes correlates with vascularity but not graft size. Stem Cell Res 2009, 3:106-112.

79. Hudson W, Collins MC, deFreitas D, Sun YS, Muller-Borer B, Kypson AP: Beating and arrested intramyocardial injections are associated with significant mechanical loss: implications for cardiac cell transplantation. J Surg Res 2007, 142:263-267.

80. Ieda M, Fu JD, Delgado-Olguin P, Vedantham V, Hayashi Y, Bruneau BG, Srivastava D: Direct reprogramming of fibroblasts into functional cardiomyocytes by defined factors. Cell 2010, 142:375-386.

81. leda M, Tsuchihashi T, Ivey KN, Ross RS, Hong TT, Shaw RM, Srivastava D: Cardiac fibroblasts regulate myocardial proliferation through beta1 integrin signaling. Dev Cell 2009, 16:233-244.

82. Efe JA, Hilcove S, Kim J, Zhou H, Ouyang K, Wang G, Chen J, Ding S: Conversion of mouse fibroblasts into cardiomyocytes using a direct reprogramming strategy. Nat Cell Biol 2011, 13:215-222.

83. Eminli S, Foudi A, Stadtfeld M, Maherali N, Ahfeldt T, Mostoslavsky G, Hock H, Hochedlinger K: Differentiation stage determines potential of hematopoietic cells for reprogramming into induced pluripotent stem cells. Nat Genet 2009, 41:968-976.

84. Hanna J, Markoulaki S, Schorderet P, Carey BW, Beard C, Wernig M, Creyghton MP, Steine EJ, Cassady JP, Foreman R, Lengner CJ, Dausman JA, Jaenisch R: Direct reprogramming of terminally differentiated mature B lymphocytes to pluripotency. Cell 2008, 133:250-264.

85. Utikal J, Maherali N, Kulalert W, Hochedlinger K: Sox2 is dispensable for the reprogramming of melanocytes and melanoma cells into induced pluripotent stem cells. J Cell Sci 2009, 122:3502-3510.

86. Stadtfeld M, Brennand K, Hochedlinger K: Reprogramming of pancreatic beta cells into induced pluripotent stem cells. Curr Biol 2008, 18:890-894.

87. Kim JB, Zaehres H, Wu G, Gentile L, Ko K, Sebastiano V, Araúzo-Bravo MJ, Ruau D, Han DW, Zenke M, Schöler HR: Pluripotent stem cells induced from adult neural stem cells by reprogramming with two factors. Nature 2008, 454:646-650.

88. Eminli S, Utikal J, Arnold K, Jaenisch R, Hochedlinger K: Reprogramming of neural progenitor cells into induced pluripotent stem cells in the absence of exogenous Sox2 expression. Stem Cells 2008, 26:2467-2474.

89. Polo JM, Liu S, Figueroa ME, Kulalert W, Eminli S, Tan KY, Apostolou E, Stadtfeld M, LiY, Shioda T, Natesan S, Wagers AJ, Melnick A, Evans T, Hochedlinger K: Cell type of origin influences the molecular and functional properties of mouse induced pluripotent stem cells. Nat Biotechnol 2010, 28:848-855.

90. Kim K, Doi A, Wen B, Ng K, Zhao R, Cahan P, Kim J, Aryee MJ, Ji H, Ehrlich LI, Yabuuchi A, Takeuchi A, Cunniff KC, Hongguang H, McKinney-Freeman S, Naveiras O, Yoon TJ, Irizarry RA, Jung N, Seita J, Hanna J, Murakami P, Jaenisch R, Weissleder R, Orkin SH, Weissman IL, Feinberg AP, Daley GQ: Epigenetic memory in induced pluripotent stem cells. Nature 2010, 467:285-290.

\section{doi:10.1186/scrt85}

Cite this article as: LU T-Y, Yang L: Uses of cardiomyocytes generated from induced pluripotent stem cells. Stem Cell Research \& Therapy 2011, 2:44. 